\title{
BANI 'ALAWIYYIN IN INDONESIA AND THE MALAY WORLD Network, Development and the Role of Institution in Transmitting the Peaceful Mission of Islam ${ }^{1}$
}

\author{
Suparto | UIN Syarif Hidayatullah Jakarta - Indonesia \\ Halid | UIN Syarif Hidayatullah Jakarta - Indonesia \\ Samsul Adabi bin Mamat | Universiti Kebangsaan Malaysia \\ Corresponding author: halid@uinjkt.ac.id
}

\begin{abstract}
Bani 'Alawiyyin is Arabian Muslims community scattering around the world. Their diaspora is due to many factors and motivations: religion (mission), economy, politic, culture, and so on. They are well-known as a community who hold tenacious principle in disseminating Islamic teaching based on the principle of rahmatan lil 'álamin (blessing to universe). This article endeavors to cast light upon socialreligious activities that have been practiced by Bani 'Alawiyyin prioritizing the courtesy aspects of all mankind. This article is also aiming at presenting data findings which can explain that Bani 'Alawiyyin had truly proselytized non-radical mission among people in Southeast Asia: Indonesia, Singapore, and Malaysia. This article also elucidates the role of Bani 'Alawiyyin especially in the form of institutional organization in transmitting Islamic doctrine in a peaceful mission. The finding shows that many organization are used by Bani 'Alawiyyin to spread Islamic teaching in different countries that lead to the success of their mission by determining local and indigenous factors.
\end{abstract}

Keywords: 'Alawiyyin, Hadhramaut, intellectual transmission, religious network, peaceful mission.

\section{Introduction}

In general, 'Alawiyyin or Bani 'Alawiyyin is Arabian Muslim community from Hadhramaut holding the lineage of Imam 'Ali bin Abu Tălib RA and Fạtimah Az-Zahrah (the daughter of Rasulullah

\footnotetext{
1 This article is abridged from the research report of the role of Bani 'Alawiyyin Institution in Indonesia, Singapore, and Malaysia, funded by the Center of Research and Publishing (Pusat Penelitian dan Penerbitan) - LP2M UIN Syarif Hidayatullah Jakarta on October 2016.
} 
SAW). Some sources say that they are the generations of Imam "Alawi bin 'Ubaidillah bin Aḥmād "Al-Muhäjir". 2 The first opinion (to Imam 'Ali bin Abu Tálib RA) seems more general that covers the whole generation of Rasulullah SAW from Imam 'Ali RA and Sayyidah Fatimah Az-Zahrah. The second opinion tends to be more focused on the generation of Imam 'Alawi bin Ubaidillah from Hadhramaut. This research is likely to be noteworthy on the second opinion, i.e. Bani 'Alawiyyin from Hadhramaut. They are also known as habib, sayyid, or syarif whose majority community spreads in several countries, especially in the Middle East and Southeast Asia.

In transmitting Islamic teaching, Bani 'Alawiyyin also can afford to build positive and productive synergy, for lower, middle, and high class society (elite and entrepreneur). This had been showed by the early arrival of Islamic preachers in Southeast Asia regions (i.e., Wali Songo) who can assimilate and acculturate the local wisdom with local society.

Referring to some historical sources, the history of Islam arrival and development in the Far East (including Indonesia, Malaysia, and Singapore), are always connected to the mainstream point of view of three theories adhered by historians: Indian, Arabian, and Persian theory. ${ }^{3}$ Azyumardi Azra is one of the historians who comprehensively explains about it, including the historical evidences mentioned by scholars — those who agree and disagree — of the three theories. ${ }^{4}$

They propagated Islam in Nusantara without accompanied by their family. Regardless of their condition, whether they are single, married, divorced, or (it is supposed to be) their wives had allowed them to do it; there is no clear explanation about it. Therefore, besides running a trade and conducting propagation, they also get married to indigenous women: especially the respected and high class women, such as the

\footnotetext{
${ }^{2}$ See Abdurrahman bin Muhammad Al-Masyhur, Syams Az̧-Zhabirah fi Nasab Abl AlBait min Banī 'Alawì Furū' Fäthimah Az-Zabrä' wa Amì Al-Mu'minin 'Alì bin Abi Thalib (Jeddah: Alam Al-Ma'rifah, 1983), p. 9.

${ }^{3}$ In general, historians have different opinion about the theories. See Nor Huda, Islam Nusantara: Sejarah Sosial Intelektual Islam di Indonesia (Yogyakarta: Ar-Ruzz Media, 2013); Agus Sunyoto, Wali Songo: Rekonstruksi Sejaah yang Disingkirkan (Jakarta: Trans Pustaka, 2011).

4 See Azyumardi Azra, "Islamisasi Nusantara; Dakwah Damai" in his book Peran Dakwah Damai Habaib 'Alawiyyin di Nusantara (Yogyakarta: Rausyan Fikr Institute and ICRO, 2013).
} 
royal family and the other high class women. ${ }^{5}$ This research studies the role of Bani 'Alawiyyin and its religious-social institutions in disseminating peaceful Islamic teaching, especially in Indonesia, Malaysia, and Singapore.

\section{Genealogy and Diaspora of Bani 'Alawiyyin}

Among of the sources that can be considered as reference of Genealogy of Bani 'Alawiyyin is Syams Azh-Zhabirah fi Nasab Abl AlBait min Banì 'Alawi Furü' Fäthimah Az-Zabrä' wa Amir Al-Mu'minin 'Alī RA-further written Syams Ažb-Zhabirah. The work of Al-Allamah AsSayyid Asy-Syarif Abdurrahman bin Muhammad bin Husein AlMasyhur. ${ }^{6}$

In the early beginning, the terms genealogy of Imam Ali bin Abu Thalib and Sayyidah Fatimah Az-Zahra was called as Ablul Bait. Then in the later time, however, it began to appear a term "Alawiyyin" referred to Imam Alawi bin Abdullah (Ubaidillah) bin Ahmad AlMuhajir bin Isa. The term Bani Alawi (or Ba Alawy) is also referred to the offspring of those who came from Hadhramaut, Yamen, and other regions of the country. ${ }^{7}$ Nevertheless, some people say that the term "Alawiyyin" is lineated to the generation of Al-Imam Ali bin Abu Thalib RA (the ancestor of Bani "Alawiyyin; the husband of Muhammad's daughter, Fạtimah Az-Zahrah RA-writer). In general, the name of "Bani Alawi" in many countries, such as south in Yamen (Hadhramaut), Hijaz (Makkah and Madinah), and the neighboring countries, mostly refer to Imam Alawi bin Ubaidillah bin Ahmad AlMuhajir. ${ }^{8}$

The Hadhramaut Arab community uses ships from large ports such as Mukalla and Shihr as transportation to travel to several

\footnotetext{
${ }^{5}$ Raden Rahmat or Sunan Ampel, before arriving at Nusantara, had an aunt who got married with Majapahit royal family and so did Maulana Malik Ibrahim (Sunan Gresik) some historians said that he is the father of Sunan Ampel. Maulana Ishaq also engaged the princess of king of Blambangan. The historical evidences showed that there had been ethnical inter-married and inter-nations.

${ }^{6}$ In printed version of publisher: Alam Al-Ma'rifah, Jeddah, Arab Saudi, the book was first printed in 1983. The book (Kitab) had been corrected by Muhammad Dhiya' Syihab. Kitab Syams Azh-Zhabirah consists of two volume explaining about history and the spread of Bani 'Alawiyyin in the world, including Indonesia.

7 Al-Masyhur, Syams Až-Zhabirah, p. 9.

8 Ibid., p. 64.
} 
countries, especially in the eastern region through the Indian Ocean. In this case, Iain Walker notes that the Hadhramaut Arab used Ships frequenting the Hadrami ports of Mukalla and Shihr were ready to carry passengers as far as their coins would take them: a dollar to Mombasa, a few more to Surabaya. A long history of emigration meant that a Hadrami arriving in almost any port on the Indian Ocean littoral could find a compatriot ready to assist. ${ }^{9}$

One of them has arrived and stayed in Indonesia, such as Sayyid Jamaluddin Al-Husein is known as Maulana Husein Jumadil Kubro, Syaikh Jumadil Kubro, or Husein Jamaluddin Akbar. Some historians distinguish between Sayyid Jamaluddin Al-Husein and Syaikh Jumadil Kubro or Maulana Jumadil Kubro. The last one is the figure of Islamic preacher who promoted Islam in Gresik and died in Tusura Bugis, South Suawesi. ${ }^{10}$

Jamaluddin Al-Husein has three sons, whose next generation become Islamic preachers. They are Sayyid Barakat Zainal Alam, Ibrahim Zain Al-Akbar and Ali Nurul Alam. Barakat Zainal Alam settled down in Gujarat India and had a son Maulana Malik Ibrahim known as Sunan Gresik, the eldest figure of wali songo (nine religious [pious] figures). On the other hand, Ibrahim Al-Akbar is the grandfather of Sunan Ampel. Therefore, Sunan Ampel is the nephew of Sunan Gresik. ${ }^{11}$ In many historical notes, it is usually mentioned that Sayyid Jamaluddin can be embraced as the grandfather of Maulana Malik Ibrahim known as Sunan Gresik, who disseminated Islam in Nusantara. ${ }^{12}$ As a spreading of dakwah in Nusantara (Indonesia),

\footnotetext{
${ }^{9}$ Ian Walker, "A Diaspora for Others: Hadramis in the World," in Nando Sigona et.al., Diasporas Reimagined: Spaces, Practices and Belonging (UK: Oxford Diasporas Program, 2015), p. 84.

${ }^{10}$ Idrus Alwi Al-Masyhur, Membongkear Kebohongan Sejarah dan Silsilah Keturunan Nabi SAW di Indonesia (Jakarta: Saraz Publishing, 2012), p. 158. Various literatures tell Sayyid Husein Jumadil Kubro conducts a trip to Maghribi in Maroko, Samarqand, Uzbekistan, untill Kelantan, Malaysia, and Java island during the era Majapahit kingdom, and the last pitstop is in Gowa, South Sulawesi.

11 Other version said that Sunan Ampel is the son of Ibrahim Zain Al-Akbar, so that between Sunan Ampel is the cousin of Sunan Gresik, not his nephew. The explanation about it can be seen in Alwi Al-Masyhur, Membongkar Kebohongan Sejarah dan Silsilah Keturunan Nabi SAW di Indonesia, p. 160.

${ }^{12}$ See the article of Muhammad bin Abdurrahman Al-Junaid Jamalullail, "Syariff AlAwliyā'” (paper presented at Al-Halaqah Al-'Ilmiyyah Al-Ūlā on January 12-14, 2016 in Hotel Kartika Chandra, Jakarta).
} 
Malaysia has a ulama in modern era, like Sayyid Alwi bin Tahir AlHaddad well-known as a progressive thinker and brilliant social critic. ${ }^{13}$ In Malaysia, study of spread of 'Alawiyyin (Hadhramaut) held at International Conference in International Islamic University Malaysia was held in August, $26-28,2005$. The conference was officiated by Dato' Sri Syed Hamid Albar (Minister of Foreign Affairs of Malaysia). The Minister highlighted the distinctive features of the YemeniHadrami diaspora in Southeast Asia, its patterns of integration and assimilation, and the role played by the Hadrami scholars in shaping Islamic thought in the region. He emphasized that "the process of integration has become complete as physical appearances, language, culture, and mindset have eventually integrated with the local community. The Hadramis were then accepted as part of the community of their new nations." The Hadhramaut offspring are considered bumiputeras (son of the soil) and they enjoy special privileges under the Federal Constitution. ${ }^{14}$

It is therefore concluded that the genealogy of the early Islamic preachers in Nusantara and the neighboring countries (Malaysia and Singapore) are mostly the descendants of Bani 'Alawiyyin from Hadhramaut. This conclusion is strongly believed that the dissemination of Islam in several countries-China, India, and other regions in Asia - are supposed to be derived from Bani 'Alawiyyin in Hadhramaut.

Bani 'Alawiyyin, in Hadhramaut, travelled many countries via large harbors of the places. Natalie Mobini-Kesheh said that at least there are two harbors in Hadhramaut as the object of migration: Mukalla and Shihr Harbors, the Indian ocean. ${ }^{15}$ From these two harbors, they sailed into Malabar in South India. They continued to Sri Lanka, to Malay Aceh, Malaysia, Singapore, and the last settled down in Sumatera. Hence, there are many Arabians descendants in Sumatera,

\footnotetext{
${ }^{13}$ For more study about Sayyid Alwi bin Tahir Al-Haddad, see Nurul Wahidah Fauzi, Abdullah Yusuf, Tarek Ladjal, and Mohd Roslan Mohd Nor, "Hadhrami 'Ulama' Within the Malay-Johor Activism: The Role of Sayyid 'Alw Bin Tahir al-Haddad (19341961)," Middle-East Journal of Scientific Research, 13, 3 (2013): pp. 345 - 362.

14 See Ahmed Abushouk, "The Yemeni-Hadramis in Southeast Asia," Intellectual Discourse, 13, 2 (December, 2005), p. 240.

15 See Natalie Mobini-Kesheh, The Hadrami Awakening; Community and Identity in the Netherlands East Indies, 1900 - 1942 (Ithaca-New York: SEAP, 1999), p. 17.
} 
such as in Aceh, Deli, and Palembang. While the other groups continued their migration to Kalimantan, Java, and Sulawesi.

The diaspora of Bani "Alawiyyin to many countries in the world, particularly in the Southeast Asia, had several approaches and specific social interaction. The dissemination background is likely to lean on their own consciousness supported by religious, social, and economical spirit. Max Webber stated that senses of belonging are usually caused by religion, history, and language which can reinforce the pillars of community building. ${ }^{16}$ Their major goals are to disseminate Islamic teaching as well as to practice their business with the societies in the places of their arrival.

Hadhramaut community built a new group, as part of religious strategy, supported by cultural, economic, religious and political motives. Such this community also brings social interaction with specific goal and interest. In this context, the migration activities of Bani 'Alawiyyin are not only to conduct a pleasure trip, but also it also has certain goal. Through the interaction of social identity, one group can interact with another group by forming public social identity. The identity is supposed to build the uniqueness and dual concepts: one can be identified by the other (in structural position) which become individual character or can be differentiated by themselves. ${ }^{17}$

During the Dutch and Portuguese colonial period, they mostly migrated to Nusantara to colonize and to exploit the natural resources. Therefore, Bani 'Alawiyyin set a goal to disseminate Islam and to conduct a commercial business and trade. ${ }^{18}$ Such the goal will lead into positive effect to the national acceptance for Bani 'Alawiyyin community. Regarding to this, Syed Farid Alatas said that the Islamic preachers and colonial Portuguese had brought different effect in terms of economy and politic. ${ }^{19}$

\footnotetext{
${ }^{16}$ See Max Weber, "Ethnic Groups," in Roth G and Wittich C (eds.), Economy and Society, Vol. 1 (Berkeley and Los Angeles: University of California Press, 1978), pp. 389-95.

${ }^{17}$ See Lee Freese and Peter J. Burke, "Persons, Identities, and Social Interaction," in B. Markovsky, et al. (eds.), Advances in Group Processes, Vol. 11 (Greenwich, Conn.: JAI Press, 1994), pp. 1 - 24.

${ }_{18}$ Interview with Habib Muchsin Idrus Al-Hamid, the member of Dewan Syuro Rabithah Alawiyah, on August 02, 2016.

${ }^{19}$ Syed Farid Alatas, "Hadhramaut and the Hadhrami Diaspora: Problems in Theoretical History" in Ulrike Freitag and William G. Clarence-Smith (ed.), Hadhrami
} 
In the end, Bani 'Alawiyyin could build a new egalitarian and tolerant community, especially toward religion and culture. It is probably due to Bani 'Alawiyyin is still keeping the Islamic mission that have to come across with all mankind. This is the major motivation of Bani 'Alawiyyin in practicing a trip to several countries in Southeast Asia.

They also teach the equality among races, tribes, and positions according to Islamic teaching. People social status and nobility are usually outweighed from their properties, education, economy, and their well-being, instead of their faith (taqwa). ${ }^{20}$ In this context, local societies, in Southeast Asia, are divided into social classes based on their races and tribes that seem to be pleasure on the teaching of Bani 'Alawiyyin. Moreover, the local people whose majority adhere animism cult, as well as Hindu-Budha, for the lower social class.

Those are the descriptions of assimilation and acculturation process done by the early Islamic preachers in Nusantara. They bring their mission without destructing and shifting local traditions. They will combine local wisdom and tradition in transmitting Islamic teaching. These are the wise strategy and approach that should be applied in disseminating Islam in the universe.

\section{Radicalism, De-radicalism, and the Implication}

Islam is an alluring religion prioritizing on a peaceful teaching as it has been explained in many verses of Holy Quran, such as the merciful apostolate of prophet Muhammad SAW in the universe, as well as the choice of believing in religion. ${ }^{21}$ Islam also encourages people to show the values of humanity and wisdom of social interaction with other non-Muslim community, ${ }^{22}$ In the context of apostolate, Muhammad SAW was delegated to bring peaceful teaching, not against other

Traders, Scholars and Statesmen in the Indian Ocean, 1750s - 1960s (Leiden: Brill, 1997), p. 23.

${ }^{20}$ In surah Al-Hujurat [49] verse-13, “O mankind! We created you from a single (pair) of a male and a female, and made you into nations and tribes, that ye may know each other (not that ye may despise (each other). Verily the most honoured of you in the sight of Allah is (he who is) the most righteous of you. And Allah has full knowledge and is well acquainted (with all things)l."

${ }^{21}$ QS. Al-Anbiya [21] verse 107 and QS. Al-Baqarah [2] verse 256.

22 QS. An-Nahl [16] verse 125 explains about the principles of preaching. 
religions, but to conduct social justice as well as individual freedom of adhering religion.

It is important to know that radicalism is not only found in Islam, but it is also found in many other religions. They commonly see religion exclusively and literally. The opposite groups are considered as impediment which can lead into detestation, anarchism, and terrorism. In general, there are two factors that bring a thought and inclination of internal and external radicalism and extremism.

The first factor (internal) is relating to Muslims thought of religious textual sources (Quran and Hadith) and also the influence of diverging and distorting figures. Since there are many evidences in the historical notes, such as the emergence of Khawarij community who interpret the Holy Quran literally and politically. ${ }^{23}$ Probably it is caused by the terms of verses in the Holy Quran which tend to encourage people to be radicalisms group and extremists. Those who see the religious texts incomprehensively and out of context will lead into radical mindset and view. Moreover, if it is supported by radical figures who encourage to conduct jihad (to engage in holy war) against the disbelievers and hypocrites, it can trigger a social radicalism and anarchism.

The second factors (external) are relating to the dynamics of secular-global society and the irrespective people to see religion properly and wisely. In the modern-globalization context, for example, it can be a trigger of having antipathy demeanor toward religion, particularly Islam. For such modernism and secularism, there must be the causes that can bring a religion into marginal position. Therefore, they are considered as an out of date object and insensibility as well as modernism barriers. The other external factors are due to the predominantly politics of Islam civilization adversary. Western societies (politicians), who are anti-Islam, mostly consider Islam as a radical and exclusive religion.

In Indonesia context, the roots of radicalism can be traced from some religious organizations and figures who have an exclusive view and place Islam vis a vis the state, Islam vis a vis hegemony of global capitalism, and so on. Akh. Muzakki, for example, notes several religious organizations involved in various conflicts that occurred in several regions of Indonesia, such as Jama'ah Islamiyah (JI), Majelis

${ }^{23}$ In verse 73 surah At-Taubah and verse 9 surah At-Tahrim ordering prophet Muhammad SAW to conduct jihad (struggle) against disbelievers and hypocraters. 
Mujabidin Indonesia (MMI), Laskar Jihad (LJ), and Front Pembela Islam (FPI). ${ }^{24}$

Warsito Raharjo Jati has similar opinion as mentioned above. In the emergence of radicalism, Jati tend to refer a political economic perspective, where the New Order and capitalist policies seek to marginalize Muslims in controlling the economic sector. ${ }^{25}$

One of the effort to prevent radicalism is by countering radicalism which is known as "deradicalization". Indonesia is the country which persistently struggle against radicalism. ${ }^{26}$ The official institution of Indonesian government through Badan Nasional Penanggulangan Terrorisme (National Counterterrorism Center) engages programs and agenda of action to counter radicalism through deradicalization programs. The goal of this program is to enlighten terrorists or groups of people who commit violence to become aware and to get rid of themselves from terrorism activities. In other words, the goals of deradicalization are: First, to end up terrorists of committing violence and terrorism activities. Second, to indulge and to support them of having moderate and tolerant perspective. Third, to encourage radicalists and terrorists in promoting and developing national programs of Negara Kesatuan Republik Indonesia (The United Nation of Republic of Indonesia). ${ }^{27}$

The effects of radical and extreme motions are the destructions of the intrinsic values of Islam as a religion of rabmatan lil alamin (as the merciful religion in the universe). In addition to this, they (extremists) can reduce and abate the apprehensive attitude toward the local values and cultures as well as the aspects of pluralism, humanism, and tolerance that can cause the appearance of radical communities.

\footnotetext{
24 See Akh. Muzakki, "The Roots, Strategies, and Popular Perception of Islamic Radicalism in Indonesia," Journal of Indonesian Islam, 08, 01 (June 2014), p. 3.

25 See Wasisto Raharjo Jati, "Radicalism in the Perspective of Islamic Populism: Trajectory of Political Islam in Indonesia," Journal of Indonesian Islam, 7, 2 (December 2013), pp. $276-277$.

26 Compared than other two neighboring countries (Singapore and Malaysia), Indonesia tends to have more terror from the radicalists. The series of bombs from radicalists-exstremists on behalf of jihad, happen very often in Indonesia, from Bali 1 (October 12, 2002) and Bali 2 (October 01, 2005) that killed hundred of victims, injure and death, untill the last bomb in Jalan Thamrin Jakarta on Januari 142016.

27 See official website of BNPT: https://damailahindonesiaku.com/deradikalisasi/ (accessed September 14, 2016).
} 


\section{Transmission, Network, and Strategy of Non-Radical Mission}

The following description and analysis of data explain about the role of peaceful preacher from Bani 'Alawiyyin, starting from the basic teaching until the strategy and social development. In here, there will be explained some samples practiced by outstanding activists, figures, and institutions where the role of Bani 'Alawiyyin are applied.

\section{The Principle of Teaching}

Based on its genealogy, Bani 'Alawiyyin is supposed to be the most difficult task in proselytizing Islamic teaching as their ancestor, Muhammad SAW, the messenger of God and the founder of Islamic teaching. Therefore, the main sources of Islamic teaching must be conducted properly and wisely. The strong principle to hold on the Quran and Muhammad tradition (badits) become the basic teaching of Bani 'Alawiyyin in practicing their daily activities, including the Islamic preach activities and social activities in general. It is the basic principle that Bani 'Alawiyyin have to show to many people to hold on the Quran and hadiths, besides their generosity and courage. This character must be accompanied by, not only to show the attitude of low profile (tawadhdhu), but it also shows the truth of religion.

In addition to this, Muslims are encouraged to hold on the two Islamic major sources (Quran and Hadiths) as Bani 'Alawiyyin firmly hold on the teaching of As-Salaf Ash-Shälib. ${ }^{28}$ The understanding of assalaf ash-sälih ("Salaf Shalih") is the ancestor of Bani "Alawiyyin known for its nobility and its strong principle, virtuous, and creditable manner in religious life and get along with the other societies. Most of Bani "Alawiyyin also practice a spiritual path known as "Thariqah Alawiyah." This spiritual path is one of riyadhah rübiyyah (spiritual exercise) taught by their ancestors of salaf Bani 'Alawiyyin. The main pattern of this spiritual path refers to Al-Qur'an and the tradition of Rasulullah SAW (Hadith).

In general, Bani 'Alawiyyin follow mazhab (disciplin) of Ahlussunnah Wal Jama'ah by following the Imams Mazbab (the discipline leaders), such as Imam Ja'far Ash-Shadiq, Imam Hanafi,

${ }^{28}$ Sayid Muhammad Ahmad Asy-Syathiri in his work Sirah As-Salaf min Banī 'Alawi AlHusainiyyin (was first published in Alam Al-Ma'rifah, Jeddah, Arab Saudi, in $1405 \mathrm{H}$ ) mentioned that the generations of Salaf Shalih are those who lived in the first, second, and third century of Hijrah, or in other words known as an atribute of prophet muhammad's friends, tabi'in dan tabi'it-tabi'in. 
Imam Malik, Imam Syafi'I, and Imam Ahmad. Among of these four imam mazhab, Imam Syafi'i becomes the majority mazhab practiced by Bani 'Alawiyyin. The theology of Bani 'Alawiyyin mostly follow Asy'ariyah theology and Imam Al-Ghazali as their spiritual discipline. ${ }^{29}$

The believe in holding the religious principle on (Quran and Hadiths) is continuously well-practiced. They then frequently conduct gathering activities, in terms of studying together, having discussion, and holding a small dialogue among them which is known as raubah. The strong orientation on Al-Qur'an and sunnah Rasulullah SAW then adapted as manbaj (system) in forming of cadres of Bani 'Alawiyyin. The moderate principle and friendliness become their basic principle and movement strategy. Habib Umar bin Hafizh in his speech at University of Education Faculty, Hadhramaut, conveyed that the extreme understanding in Islam had gone away from the right path. This extreme principle is categorized as ignorant and disregard of God's law, the truth of God. ${ }^{30}$

\section{The Strategy of Movement}

The strategy of movement practiced by the prominent figures and activists of Bani 'Alawiyyin are: to conduct majlis taklim, daily studies, discussion, seminar, and workshop. The other strategies are generating people development and empowerment through cultural and economic reinforcement.

The activity of religious proselytizing in one majlis taklim is categorized as the eldest and common method practiced by Bani 'Alawiyyin figures and activists due to many factors. First, they mostly refer to prophet Muhammad's method in conducting studies to convey the message from Allah SWT (Holy Quran) and his tradition (Hadiths). These activities are usually conducted in mosques and houses. The method used in this forum applies the system of halaqah, the speaker (presenter) is sitting in the middle of forum and the other members are sitting around in the left and the right side of the speaker. The format of such forum is the most common method practiced by Bani 'Alawiyyin.

\footnotetext{
${ }^{29}$ See the interview with Habib Hassan Al-Atas di Singapura on August 06, 2016; also an interview with Habib Zen Umar bin Smith (the chairman of Rabithah Alawiyah Jakarta) on August 27, 2016.

${ }^{30}$ Habib Umar bin Hafizh, Agama Moderat: Mengidupkan Kembali Hakikat Ajaran Islam (Jakarta: Nurni Publishing, 2010), p. 41.
} 
On the next stage, the formation is continually developing along with the advance of civilization and technology of communication, where the members of halaqah do not need to be present at the physical meeting. Instead, they can conduct a halaqah (forum) via Facebook, YouTube, twitter, and other social media as the instrument of learning, religious proselytizing, etc. ${ }^{31}$ Now a days, therefore, the halaqah method had undergone shifts and developments in a more broader sense.

Rabithah Alawiyah is structural organization which is more comprehensive. The programs and agenda run by Rabithah Alawiyah comprising a lot of systematic and long term strategies: vision and mission, paradigm, programs of work, charities, scholarships, services and the distribution of zakat (tithe), infaq/sadaqoh (alms), and also HIPPA (Himpunan Pengusaha dan Profesional 'Alawiyyin Indonesia / the Organization of Entrepreneurs and Professionals of 'Alawiyyin in Indonesia). ${ }^{32}$

Rabithah Alawiyah is the main organization of Bani 'Alawiyyin that has significant role in disseminating Islamic proselytizing as the religion of rahamatan lil álamin. The role and the strategy practiced by Bani Alawiyah is to support government programs through National Counterterrorism Centre (NCTC) and to counter Islamic radicalism in Indonesia.

The strategies of motion, practiced by Bani 'Alawiyyin in Indonesia, is not so far different with Bani 'Alawiyyin in Singapore and Malaysia. Ba Alawi mosque in Singapore, for example, is also actively involved in religious proselytizing and to give contribution to government of Singapore in holding a peaceful nation.

Ba Alawy mosque has very significant role for Singapore consisting of 10 religious disciplines. ${ }^{33}$ Moreover, Habib Hasan Al-

31 Intitution or majelis taklim as "Majelis Rasulullah" (Jakarta, Indonesia) established by Habib Mundzir Al-Musawa, as one of the institution that uses social media to enlarge networking of Islamic transmittion. also majelis taklim Darul Murtadza initiated by Habib Ali Zainal Abidin (Setiawangsa, Malaysia), uses the same pattern and format. Several studies forums initiated by Bani 'Alawiyyin (such as Darul Musthafa, Nurul Musthafa, and so on) also uses the same pattern.

32 See official website of Rabithah Alawiyah: http://www.rabithah-alawiyah.org/id (accessed on 29 August 2016).

33 The tenth sects are: Zoroaster, Baha'i, Jewish, Taoisme, Islam, Sikh, Hindu, Budha, and Christianity (Catolic and Protestan-writer). See: IRO: http://iro.sg/ (accessed on October 07, 2016). 
Attas as one of the Inter-Religious Organization (IRO) board is known as the tolerant and religious figure in Singapore. One of the evidences of his tolerant and inclusive character is building an inter-faith museum which is located in front of Ba Alawy mosque. ${ }^{34}$ Even though the social-religious dynamic of Bani 'Alawiyyin is not as big as in Indonesia, however, the role of the figures of Islamic preachers of Bani 'Alawiyyin is also in good position, for example Darul Murtadza managed by Habib Ali Zainal Abidin Al-Hamid. Habib Ali is one of the students and alumnus of Pesantren Darul Musthafa, Tarim, Hadhramaut managed by Habib Umar bin Hafidz. ${ }^{35}$ As the other alumni from Hadhramaut, the development of Habib Umar is almost the same as his predecessors, i.e., practicing the moderate and tolerant teaching. Habib Ali also gives more attention toward moral and virtual values brought by prophet Muhammad SAW.

Bani 'Alawiyyin in Indonesia, Singapore, and Malaysia also frequently practices silaturrabmi (courtesy [relationship] visit) among ulama and habaib. Moreover, silaturrabmi which is supported by the government of the three countries can bring a positive effect for Islamic mission as the religion of rahamatan lil álamin. Certainly, Bani "Alawiyyin has significant roles in supporting the process of "The Radicalization of Islam," as well as to counter any kinds of "Radicalization of Islam."

\section{The Narration of "Non-Radical Islam"}

The Narration of "non-radical Islam" transmitted by Bani 'Alawiyyin can be seen from the number of activities relating to Islamic mission and education. The religious organizations and institutions of Bani 'Alawiyyin in Indonesia are: Rabithah Alawiyah, ${ }^{36}$ Jami'at Kheir, ${ }^{37}$

\footnotetext{
34 Among the museum collection in the mosque are, holy books (Quran) antique Bibel and Taurah as well as other religious manuscripts. Among of the goals of the museum is to courage peace and mutual understanding among religion.

35 According to Habib Hamid Al-Qadri, the leader of Darul Murtadza Malaysia (Habib Ali Zaenal Abidin Al-Hamid) one of the board of Majelis Al-Muwasholah in Malaysia. Interview on August 02, 2016.

36 Rabithah Alawiyah was established on December 27, 1928, approaximately 2 months after declaration of Sumpah Pemuda (youth oath) on October 28, 1928.

${ }^{37}$ Jami'at Kheir is clasified as the eldest organization that have ever been established by Arabian community in 1903, but it was eccepted by Dutch government at June 17, 1905.
} 
and Majelis Al-Muwasholah. ${ }^{38}$ In Singapore, Ba Alawy mosque in Singapore is managed by Habib Hassan Al-Attas. In Malaysia, Majlis Ta'lim Darul Murtadza is managed by Habib Ali Zainal Abidin AlHamid.

Relating to the principle and concept of tranquil teaching, the activists of Bani 'Alawiyyin endeavor to purify Islamic teaching and a good moral to not get involved in political practice for Bani 'Alawiyyin. Habib Muchsin Idrus Al-Hamid, as one of the board of AlMuwasholah forum and also the vice of Rabithah Alawiyah, said as follows:

The religious missions practiced by Bani 'Alawiyyin are commonly the same: transmitting moderate and religious mission of rabamatan lil álamin (blessing to universe). The predecessors of Bani 'Alawiyyin who came to Indonesia had brought a peaceful religion, without a war. According to Habib Muchsin, the things that have been written by Western historians about Bani 'Alawiyyin who came to Indonesia to conduct commercial business is inappropriately reported. In fact, the major goal of Bani 'Alawiyyin is, certainly, to conduct religious mission. Nonetheless, it seems natural when they gradually conduct commercial trade, since the major commitment is to conduct religious mission. ${ }^{39}$

Habib Muchsin Alhamid's opinion is the same with Habib Hassan Al-Attas, the chairman of Ba'Alawy mosque in Singapore. According to Hasan, Islam is a peaceful religion which always respects local traditions. In an interview, Habib Hassan said that the early Islamic preachers who came to the Far East regions, particularly in Singapore (including Indonesia and Malaysia), had transmitted a peaceful and respectful teaching on local tradition. Habib Hassan is the one who likes to wear local clothes and tradition of the local society.

\footnotetext{
38 While Majelis Al-Muwasholah is more focus on ulama and government networking of religious mission. Majelis Al-Muwasholah was established in $1327 \mathrm{H}$ or $2007 \mathrm{M}$. The founder of Majelis Al-Muwasholah was based on Al-Habib Umar bin Muhammad bin Salim bin Hafidz's advice (known as Habib Umar bin Hafizh) from Hadhramaut, Yemen.

39 Presented by Muchsin Idrus Alhamid in FGD August 02, 2016 in Majelis AlMuwasholah.
} 
The successful religious mission of Bani 'Alawiyyin in three countries (Indonesia, Singapore, and Malaysia) is not only sharing knowledge, but also mutawassith (moderate). The Islamic preachers from Hadramaut also wear sarong, Nusantara clothes. For example, KH. Anwar Musaddad (from Garut) and KH. Abdullah Syafi'i (from Jakarta) wear sarong, batik clothes, and kopyah (Islamic-head cover). They also wear such clothes as the instrument of promoting religious mission. So, they do not change their clothes into gamis or jubah, the Arab-style-shirt... ${ }^{40}$

Habib Hasan said that the key success of Islamic mission is transmitted by using peaceful, friendly, and kinship approach toward the local tradition. For him, a peaceful mission must be based on a sincere intention as the teaching of prophet Muhammad SAW and the predecessors of Bani 'Alawiyyin. According to Habib Hasan, people should not ruin the custom or local culture that have been practiced by local societies where the Islamic preachers settle down.

The things that are also important are the use of "local language" as media in transmitting religion. The early Islamic preachers mostly applied Indonesian language in delivering their speech, not Arabic language. For example, Habib Ali bin Abdurrahman Al-Habsyi (known as Habib "Ali Kwitang") who speeches in Bahasa Indonesia. Bani 'Alawiyyin who traveled to India also do the same thing as his predecessors. They use Urdu language as media of preaching for local people in India. So, clothes can be effective media that can be used in transmitting a religious mission. ${ }^{41}$

The general chairman of Rabithah Alawiyah and Habib Zen Umar bin Smith said that it is important for Islamic preachers to use a peaceful method. ${ }^{42}$ According to Habib Zen, Muslims should appreciate and keep the local wisdom as long as it is still in lining with syari'ah (Islamic law), the rule which had been decided by Allah and His

\footnotetext{
${ }^{40}$ Interview with Habib Hassan Al-Attas, the chairman and the board of Masjid Ba Alawy, Singapore on August 022016.

${ }^{41}$ Habib Hassan Al-Attas also mentions about his father's hobby (Habib Muhammad bin Salim Al-Attas) wearing sarong. He introduce the clothes (sarong) to his friends in Hadhramaut as "sarong," not in Arabic language "izar." It is also mentioned as "kain panas" or "kaos singlet" worn by Javanese-Malay. It indicates that his father realy appreciate local tradition and culture in Singapore. Interview with Habib Hassan AlAttas, the chairman of Ba Alawy mosque, Singapore, on August 06, 2016.

42 Habib Zen Umar bin Smith was elected as the general chairman of second period (2016 - 2021) in Muktamar Nasional XXIV Rabithah Alawiyah on August 02, 2016.
} 
messenger. Sometimes such this local wisdom is destructed because of incomplete understanding and taken for granted. This is the things that can spoil the face of tranquil Islam. Moreover, the role of radical Wahabi which can ruin the local tradition and input the radical tradition. For example, the case of wearing veil for Indonesian Muslim women. 43

According to Habib Zen Umar bin Smith (the general chief of Rabithah Alawiyah Jakarta 2016-2021), Islam is a religion of peace and it probably can be violated by certain people from the Muslims themselves. It is important to think critically and selectively toward many teachings and tradition which is still developing. For example, the tradition of Hadhramaut is certainly different with Indonesian tradition. The most important thing is to appreciate to each other and should not spoil the basic principle of Islam. ${ }^{44}$

Habib Zen has the same opinion as Habib Abu Bakar Al-Adni, the well-known ulema from Aden, Yamen. According to him (Abu Bakar), radicalism basically has the same pattern as the endemic (infectious disease), such as cholera, smallpox, and of its kinds. Islam is the most perfect solution to overcome many problems of mankind. Radicalism is basically created by "Satan" (read the tragedy of the killed Habil writer). So, radicalism is "Satan troops" who want to disseminate disorder on earth. Since Islam will never allow people-blood-spill. 45

Several explanations above show that Islamic teaching brought by Bani 'Alawiyyin is a religious dissemination for a peace, affection, and appreciate universal human values.

\section{Religious Networking and Intellectual Transmission}

In several regions in Southeast Asia, there are at least three influential ulama of Bani 'Alawiyyin, such as Sayyid Muhammad bin Alawi Al-Maliki Al-Hasani who becomes the advisory board of majelis ilmu in Rusaefah, Makkah Al-Mukarramah. During the 1980s until the

\footnotetext{
${ }^{43}$ Interview with Habib Zen Umar bin Smith on August 27, 2016. Habib Zen has opinion that veil isnot local tradition (Indonesia) but it is imported from other countries Indonesia (particularly Central Java) spreaded by radicalists of Wahabi.

${ }^{44}$ Interview with Habib Zen Umar bin Smith on August 27, 2016.

${ }^{45}$ Habib Abu Bakar's opinion can be read on his paper and speech presented in the seminar "Peran Madrasah An-Namath Al-Ausath dalam Penyebaran Islam dan Pembangunan Konsep Kehidupan Yang Damai di Wilayah Asia Timur" held on 12 January 14, 2016 in Hotel Kartika Chandra, Jakarta.
} 
first 2000s, Sayyid Muhammad bin Alawi frequently visits several pesantren (Islamic boarding school) and majelis ilmu in many countries in Southeast Asia, such as Indonesia, Malaysia, Singapore, Philippine, and so on. There are many ulama and religious figures have ever been Sayyid Muhammad's students and his father (Sayyid Alawi), such as KH Maimun Zubair (Rembang, Central Java), KH Luhtfi Bashori (Malang, East Java), and Habib Thahir Alkaf (Tegal, Central Java). Now, Sayyid Muhammad's mission continued by his son, Sayyid Ahmad bin Muhammad Al-Maliki.

Besides the ulama of makkah, the other influential figures who has wide networking in Souteast Asia is Habib Umar bin Muhammad bin Hafizh (known as Habib Umar bin Hafidz). He is the advisory board of pesantren Darul Musthafa, Tarim, Hadhramaut. While Habib Umar is the one who ever visited Indonesia, after Sayyid Muhammad bin Alawi Al-Maliki. Even though they are from different countries, but both of them are the students of Indonesia.

Habib Umar bin Hafizh visited Indonesia for the first time on $1414 \mathrm{H}$ (approximately $1994 \mathrm{M}$ ). This visit has positive effect for many Indonesian students who studied in Tarim, Hadhramaut. Indonesian students are considered as the first students who studied in Tarim, Hadhramaut. At that time of $1416 \mathrm{H}(1996 \mathrm{M})$ there are about 30 students. Until $1421 \mathrm{H}(2002 \mathrm{M})$, the number of student from Indonesia in Darul Musthafa is about 400 students. ${ }^{46}$

In addition to the two ulama above, there is also Habib Abu Bakar Al-Adni bin Ali Al-Masyhur, from Aden, Yamen. As the other ulama from Hadhramaut, Abu Bakar Al-Adni also has many students and followers from all over the world, including Indonesia. Despite of Habib Abu Bakar lately has visited Indonesia, but he frequently visits several seminars and religious ceremonies. One of his influential opinion is the concept of Fiqh At-Tabawmulat (Fiqh of Transformation) $\cdot{ }^{47}$

\footnotetext{
46 See the sites https://pecintahabibana.wordpress.com/2013/02/07/profil-darulmusthofa-tarim-hadhramaut// (accessed September 09 2016).

47 The core of Fiqh Tahawwulat is to understand the base of Islam $4^{\text {th }}$, alamatus saa'ah (the signs of end of world/judmentday). The three requirements had been known by muslims from hadits about: 1) faith 2) Islam; and 3) Ihsan. Habib Abu Bakar tries to interprete the $4^{\text {th }}$ requirements in the context of dynamic and comtemporer of modern muslims.
} 
In Malaysia, he had ever conducted International seminar entitled "Fiqh Tahawwulat: religious proselytizing Seminar of Habib Abu Bakar bin Ali Al-Masyhur." The Seminar was held on May 4, 2015 in an Auditorium of Yayasan (foundation) Restu, Shah Alam, Selangor. In Singapore, there are many Islamic studies forum (majlis) founded by Alawiyyin. Among of the Majlis Muwasolah in Singapore. This majelis (forum) also can be found in Indonesia. The chairman of this Majlis Muwasolah in Southeast Asia is Habib Muhammad Al-Junaid from Singapore. In Indonesia is managed by Habib Hamid Al-Gadri. 48

Observing the role of ulama in the Middle East and Hadhramaut above, it can be concluded that there is a strong networking of 'Alawiyyin (and the ulama of non-'Alawiyyin) in disseminating peaceful religious preach values in many countries all over the world, especially in the Southeast Asia. This becomes the religious networking and intellectual transmission that must be supported and developed by societies and government. It is important to know that everyone is required to keep the principle of ukhuwwah islamiyyah (islamic brotherhood), ukhuwwah wathaniyyah (national brotherhood), and ukbuwwab insaniyyah (humanitarian brotherhood). Besides, such the effort is to counter radicalism-extremism that can lead to anarchism and terrorism as the public enemy of universal human civilization.

\section{The Development and the Role of Institution}

Almost all organization or institution cultivated by Bani 'Alawiyyin are always developed by giving social morality. Therefore, automatically they conduct the religious mission to all Muslims. The main organization of Bani 'Alawiyyin Indonesia is Rabithah Alawiyah. This organization has motto "Lets enhance our moral, education, and prosperity." This organization has several branches and regions boards scattered around Indonesia.

Ba Alawy mosque in Singapore is managed by Habib Hassan AlAttas. This mosque is not only functioned as the place of ritual, but it is also used as media to conduct religious proselytizing and the other activities, including the storage of Manu scriptures and the other historical materials from all over the world. Ba Alawy mosque also has function as museum and a place for dialogues of many people problems, especially in Singapore. Rabithah Alawiyah and Masjid Ba

48 Information of Majelis Muwasholah can be obtained from one of its board, Aziz. 
Alawy in Singapore are different with Indonesia. Therefore, Majlis Ta'lim Darul Murtadza managed by Habib Ali Zainal Abidin, focuses on studies forum as a model of human development.

The following are the religious institutions and organization run by Bani 'Alawiyyin, which is especially involved in the field of religious mission, education, and development. Several institutions and organizations which will be explained below are the representation of the other several institutions and organizations. The institutions and organizations can be an important confirmation of data about the role of Bani 'Alawiyyin in spreading the principles and peaceful religious missions, as well as to counter the emergence of Islamic radicalism.

\section{Rabithah Alawiyah}

Rabithah Alawiyah as the main body of all institutions and organizations of Bani 'Alawiyyin, including non-political organization which is more concerned in developing moral and empowering Islam society. Among of the programs managed by Rabithah Alawiyah are the scholarship distribution for Bani 'Alawiyyin students who live to be in wanted and poverty. Rabithah Alawiyah also distribute donations, zakat, infaq, and shadaqah (ZIS) for mustadh'afin (poor people). Rabithah Alawiyah also provides operational vehicles (ambulances and other vehicles) for accomodation or to bring and carry corpses. The characteristics of Rabithah Alawiyah are the special devision to registering lineage descendants known as Maktab Ad-Daimi. ${ }^{49}$

Development Programs and empowerment of Rabithah then continuously developed and it is expected as one of the institution or organization that can help poor and those who live in wanted. One of the programs applied by Rabithah Alawiyah is the establishment of Himpunan Pengusaba dan Profesional 'Alawiyyin Indonesia (HIPPA Indonesia). The goal of the establishment of HIPPA in Indonesia is to create networking among entrepreneurs and professionals as well as the empowerment of young generation of 'Alawiyyin in Indonesia

\footnotetext{
${ }^{49}$ Maktab Daimi is the only institution under Rabithah Alawiyah which can certify the lineage of 'Alawiyyin. See http://rabithah-alawiyah.org/id/urusan-nasabmaktabdaimi/ (accessed on August 29 2016).
} 
which is later expected can affect for life development quality of 'Alawiyyin in general. 50

In one meeting of Dewan Pimpinan Pusat (DPP) Rabithah Alawiyah in Jakarta, there are many programs and agenda which had been completed and are ongoing by the boards of Rabithah. The Programs are divided into several aspects: religious and mission; education and human resources; organization and institutional networking; Economy, Social, and empowerment; Technology and Information system; and youth generation. ${ }^{51}$

The explanation above shows that Rabithah Alawiyah pays a lot of attention and consciousness in developing organization of Rabithah in the future. Such this development is considered very significant, since there will be many dynamic and complicated challenges in the future. The organization of Rabithah has to be responsive and anticipative to every local, national, and international problems of society.

In the context of human development, Rabithah always coordinates and creates notworking with many institutions, government and non-government. It can be seen from the boards of Rabithah who become the member of Indonesian Ulama Council/Majelis Ulama Indonesia (MUI). Some Rabithah boards develop their own institution and organization, such as Majelis AlMuwasholah managed by Habib Muchsin Alhamid and Hamid Ja'far Al-Qadri. ${ }^{52}$ There are also several studies forums (majelis ilmu), such as Majelis Rasulullah established by Habib Munzir Al-Musawa. ${ }^{53}$ There are also other institutions or studies forums established by Bani 'Alawiyyin. In addition to this, some boards of Rabithah Alawiyah also have educational background as researchers, academicist, such as

\footnotetext{
${ }^{50}$ HIPPA 'Alawiyyin was established on September 17, 2011 under Habib Zen Umar bin Smith his first period, see http://rabithah-alawiyah.org/id/hippa-2/ (accessed on August 29 2016).

51 Meeting with DPP Rabithah Alawiyah on August 27, 2016.

52 Habib Muchsin Idrus Alhamid is one of the advisory board of Majelis AlMuwasholah and also as vice of Rabithah Alawiyah. Habib Hamid Ja'far Al-Qadri is the leader of Majelis Al-Muwasholah who is also one of the board member of Religious and Preach in Rabithah Alawiyah.

${ }^{53}$ Now, Majelis Rasulullah developed by Habib Munzir, i.e., Habib Nabil Fuad AlMusawa who is also one of the member board of Institution Networking of Rabithah Alawiyah.
} 
Husin Alatas P.hD, ${ }^{54}$ the rector of Jami'at Kheir University and a lecturer at Institut Pertanian Bogor (Bogor Agriculture University). Profesor Dr. Muhammad Idrus Alhamid is also a lecturer at Universitas Indonesia. 55

Based on the variety background of Rabithah boards, there has been a large potential in developing human resources for the future. In addition to this, the activists of Rabithah also have responsibility to transmitting a peaceful, and moderate Islamic teaching, which can appreciate Indonesian supreme values.

\section{Majelis Al-Muwasholah}

If Rabithah Alawiyah has function as the main body of Bani 'Alawiyyin in Indonesia, Majelis Al-Muwasholah is a social-religious institution which concerns in developing religious mission. Majelis AlMuwasholah was established by Al-Habib Umar bin Muhammad bin Hafidz (known as Habib Umar bin Hafizh), from Tarim, Hadhramaut; precisely on Muharram $1427 \mathrm{H}$ coincident with $2007 \mathrm{M}$. The full name of this institution is "Mejelis Al-Muwasholah baina Ulama AlMuslimin" (known as Majelis Al-Muwasholah).

As its name, Majelis Al-Muwasholah is focused on creating networking among ulama. The establishment background of this institution is caused by the importance of having networking among ulama from all over the world. It can be seen from its vision: to create unity and to assisting each other among of ulama in order to promote Islamic mission in the world. The missions are: to take apart in developing and producing religious ulama among Muslims societies. ${ }^{56}$

Habib Umar bin Hafizh is regarded as the role founder of Majelis Al-Muwasholah and as an international ulama from Hadhramaut. So, this institution can promote international networking. Among of the countries taking apart in establishing this Majelis Al-Muwasholah are: Indonesia, Singapore, Malaysia, Thailand, Yamen, and the other countries in the Middle East.

\footnotetext{
${ }^{54}$ Now, Habib Husin Alatas positioned as general Secretary in Rabithah Alawiyah for period 2016 - 2021.

${ }^{55}$ Now, Prof. Muhammad Idrus Alhamid positioned as Dewan Mustasyar (council of judgement) as well as the chairman of Education and Development of Human Resources of Rabithah Alawiyah for period 2016 - 2021.

56 See http://majelisalmuwasholah.org/majelis-almuwasholah/ (accessed on August 19, 2016).
} 
One of the idea which is often promoted by Habib Abu Bakar AlAdni is the concept of "Fiqh Tahawwulat," means "Transformative Fiqih." Malaysia and Singapore also promote such the same concept. Malaysia then conducts an international Seminar entitled "Fiqh Tahawwulat": A religious Seminar of Dr. Habib Abu Bakar bin Ali AlMasyhur." The Seminar was held on May 4, 2015 M. in an Auditorium of Yayasan Restu, Shah Alam, Selangor. Singapore also promotes several majlis (religious studies forum) initiated by Alawiyyin, such as Majelis Al-Muwasolah in Singapore. This Majelis is also developed in Indonesia. The chairman of Majelis Muwasolah in Southeast Asia is Habib Muhammad Al-Junaid from Singapore.

Indonesian Majelis Al-Muwasholah often conduct several activities, such as silaturrabim (courtesy relationship visit), kajian ilmiah (scientific studies), liqa or murtaqa (daily local meeting or permanent meeting. Such as "Pemuda Muwasholah" which is located in pesantren Darul Musthafa, Karangpandan-Karanganyar Solo. ${ }^{57}$ Dewan Syuro Majelis Al-Muwasholah also practices the same concept as Majelis AlMuwasholah in Central Java. This program is conducted in pondok pesantren (Islamic Boarding school) Al-Futuhiyyah, Mranggen, Demak, central Java, managed by KH. Hanif Muslih, who also occupies as Dewan Syuro (advisory council of) Majelis Al-Muwasholah in Demak, Central Java.

All programs and development activities run by Majelis AlMuwasholah are expected to create attention among of them in order to practice peaceful, friendly, and tolerant religious mission as the missions of prophet Muhammad SAW and ulama. The wide networking in many countries of Southeast Asia, enable Majelis AlMuwasholah to promote peaceful religious preach for societies and can make them realize to develop polite, affective, and tolerant attitude to the mankind.

\section{Ba Alawy Mosque in Singapore}

$\mathrm{Ba}$ Alawy mosque is the only mosque in Singapore which has its own unique, since there are a lot of historical materials in it. This mosque is like a museum which store many historical objects, such as Al-Qur'an, war appliances, mat prayers, clothes, and many other objects, such as rings, Quran cases, etc. as the result, the mosque led by

${ }^{57}$ See the official website: http://majelisalmuwasholah.org/majelis-almuwasholah/ (accessed on August 19, 2016). 
Habib Hassan Al-Attas has special characteristics as the instruments of religious proselytizing. ${ }^{58} \mathrm{Ba}$ Alawy mosque which was established by Habib Muhammad bin Salim Alatas on Dzulhijjah 19, $1372 \mathrm{H}$, coincidence with September 9, 1952 M.59

There are a lot of Muslims who visit this mosque. Some of them come from Middle East, such as Arab, Iraq, Syria, Qatar, Yamen and several neighboring countries also visit to the mosque to conduct silaturrabim (courtesy visit), or to discuss about scientific research discussion. In a program of hawl (annual ceremonial commemoration of death person) ${ }^{60}$ for Habib Muhammad Alatas which had been carried on since 1977. An English mass media entitled "Ba Alawi Mosque - a model for inclusion" told about social care in Ba Alawy mosque to help the poor and the orphans. ${ }^{61}$

Generally, Ba Alawy mosque promote inclusive, tolerant, policy, together with many institutions, government, inter-religious figures, and the all ulama. The policy that had been determined by Ba Alawy mosque can be accepted and strategic approach, since the position of Muslims in Singapore is in minority. Habib Hassan Al-Attas also active in an organization of inter-religion in Singapore, i.e., IRO (InterReligious Organization) of Singapore. IRO had been established since March 18, 1949 M. which the main goal is to promote peace, tolerance, and morality among religious societies. ${ }^{62}$

According to prime minister of Singapore, Mr Lee Hsien Loong, the establishment of IRO is to build mutual understanding among religious societies that there are 10 of them in Singapore who want to build mutual understanding among people in Singapore. ${ }^{63}$ In the

58 Observation of the writer when visited to Ba Alawy mosque in Singapore on August 06, 2016.

59 See the official website: https://www.facebook.com/Baalwie.Mosque.Singapore/ about/ (accessed on October 07, 2016).

${ }^{60} \mathrm{Hawl}$ or haul is an annual rememberence to commemorate and to pray for someone who died. It is usually carried out by praying, berdzikir, and reading shalawat (peace be upon prophet muhammad). Attended by many muslims.

${ }^{61}$ See http://www.kitaba.org/news/ba-alawi-mosque-a-model-for-inclusion/ (accessed on October 07, 2016)

62 The detail of the goal of IRO can be read in official website IRO: http://iro.sg/about/iro-objectives/ (October 07, 2016).

${ }^{63}$ Based on the information from the official sites IRO, some boards of IRO (period 2016-2017), of religions: Zoroaster, Baha'i, Jews, Taoisme, Islam, Sikh, Hindu, Budha, 
day of 66 years of IRO in Singapore (May 12, 2015), Mr. Lee Hsien handed over award to Habib Hassan Al-Attas as the chairman of $\mathrm{Ba}$ Alawy mosque who had positive contribution in building dialogue among people (inter-faith) in Singapore.

Habib Hassan Al-Attas is well-known as a tolerant religious figure in Singapore. He is not only appointed as one of the board of IRO (2016 - 2017), but he is also established as a figure who has important role in building tolerant and inclusive characters among people. One of the evidences that he is as a very tolerant and inclusive figure can be seen from the building of inter-faith museum located in the yard of Ba Alawy mosque. Among of the collections of museum in the mosque are: antique Bibel and Taurat (torah) and other religious manuscripts. The goals of the museum are to encourage a peace and mutual understanding among religion. ${ }^{64}$

Ba Alawy mosque also strategically take apart in building the tolerant and humanities generation that is far from radical and extreme values. Ba Alawy mosque develop Islamic mission as religion of rahmatan lil älamin (blessing to universe) that can be seen from one ruler to another ruler in Singapore. Every prime minister in Singapore, always appreciates the policies produced by $\mathrm{Ba}$ Alawy. Here is the strategical position and role of institution run by Habib Hassan AlAttas in creating harmonious life structure and to make peaceful relation among people.

\section{Darul Murtadza in Malaysia}

In its official sites, Darul Murtadza mentioned that Habib Ali was born on Friday, April 12, 1974, after Jumat (Friday) prayer in Bondowoso, East java, Indonesia. ${ }^{65} \mathrm{He}$ comes from humble family who lived in residential mass area where there are many ulama of pesantren. He is one of the first students of Al-Habib Umar bin Hafizh (such as Habib Mundzir, the founder of Majelis Rasulullah

Christianity (Katolik dan Protestan-writer). See : IRO: http://iro.sg/council/ (accessed on October 07, 2016)

64 See https://www.hometeam.sg/article.aspx?news_sid=20150513zPGPHt0J7QRs (accessed on October 07, 2016).

65 See http://darulmurtadza.com/habib-ali-zaenal-abidin-al-hamid-3/ (accessed on August 27, 2016). 
SAW in Jakarta, --writer). His first talent as an Islamic preacher is galvanized by $\mathrm{Al}$ Habib Umar bin Hafizh. ${ }^{66}$

Moreover, Habib Ali is included as one of Majelis Al-Muwasholah board in Setiawangsa, Malaysia where he has wide networking. Majelis Al-Muwasholah was established by an International ulama of Hadhramaut, i.e. Al-Habib Umar bin Hafizh, the chairman of Darul Musthafa in hadhramaut. Acording to Habib Ali, the initiation of Darul Murtadza is merely to send a message from his teacher, Habib Umar bin Hafizh, the charismatic ulama from Hadhramaut, Yamen. Habib Ali is the students of Habib Umar when he studied in pesantren Darul Musthafa, Hadhramaut, managed by Habib Umar bin Hafizh. ${ }^{67}$ Besides, Habib Ali feels that his activities in Darul Murtadza is to bring a mission from Habib Abdul Qadir Al-Jufri, his predecessor in Darul Murtadza.

In general, the agenda of Darul Murtadza is more focused on religious mission containing about fiqih and sirah nabawiyah (prophet history). Darul Murtadza also promotes studies and dialogues relating to daily ritual and religious faith, such as the networking of Darul Musthafa (Hadhramaut). Majelis taklim Darul Murtadza often invites his teacher-master, Al-Habib Umar bin Hafizh, as part of making relationship student and teacher.

The website of Darul Murtadza also provides services "QuestionAnswer" dedicated to visitors and the members of Darul Murtadza. In the menu of "Media," Darul Murtadza also provides subscriber-service in its official websites. There are at least 17.147 subscribers who are actively involved in the activities of Darul Murtadza via YouTube, 33.836 followers on Twitter, and 88.298 fans on Facebook. ${ }^{68}$

As the other Bani 'Alawiyyin, Habib Ali, as the chairman of Darul Murtadza, also follows mazhab (discipline of) Salafush Shalih. It is due to his ancestors who follows the trace of Rasulullah SAW and habaib who are well known for their moral piety and noble good deed. As it has been mentioned before that the majority of Bani 'Alawiyyin follow the mainstream of mazhab Ablus Sunnah Wal Jama'ah (the follower of prophet Muhammad traditions and the conjunction of ulama). In the

\footnotetext{
${ }^{66}$ See https://ahlulbaitrasulullah.blogspot.co.id/2014/03/pembina-majlis-darul-murtadza-malaysia.html

${ }^{67}$ Interview via telephone with Habib Ali Malaysia on August 10, 2016.

${ }^{68}$ See the official website darulmurtadza.com (accessed on August 27, 2016).
} 
field of fiqih (the study of law pertaining ritual obligation), he follows the discipline of Imam Syafi'i. In theology, he follows Asy'ariyah, and in tasawnf (misticism), he follows Imam Al-Ghazali. Habib Ali is also expert in Thariqah Alawiyah established by Habib Muhammad (bin Ali) "Al-Faqih Al-Muqaddam." 69

\section{Jamiat Kheir}

Jamiat Kheir (sometimes written in Jamiatul Khair or Jami'at AlKhair) is Bani 'Alawiyyin institution which is focused on educational field. Jamiat Kheir is categorized as the eldest institution initiated by Arab society in Indonesia. This institution had been established since 1898 M. At that time, several Arabian figures agreed to establish an organization to assist Arabian people. They often hold meetings of creating their goals that can assist Muslims condition and to build modern Islamic schools as their unsatisfaction toward Dutch colonial education system.

During two years of its establishment, Jamiat Kheir still didn't get official license from the Dutch colonial. Therefore, in 1903, the founders of Jamiat Kheir submitted permission proposal. However, the Dutch colonial refused it and Jamiat Kheir had just been officially admitted on June 17, 1905 M. ${ }^{70}$

The establishment of Jamiat Kheir had preceded the other movement of institution in Indonesia, such as Sarekat Dagang Indonesia (1905), Sarekat Islam (1908), Muhammadiyah (1912), and Nahdlatul Ulama (1926). Even, the heroic figures HOS Tjokroaminoto (as one of the founder of Sarekat Islam-writer) and KH. Ahmad Dahlan (the founder of Muhammadiyah) ever joint as the members of Jamiat Kheir. ${ }^{71}$

Jamiat Kheir revolt against the Dutch colonial policy using soft strategy. This opposition seems to be driven by a strong will to expel colonialism as a doctrine and ideology which is contradicted with religious and human values. According to Dr. Husin Alatas, the Dutch

\footnotetext{
${ }^{69}$ It can be seen from references books used as media of religious mission in Darul Murtadza.

${ }^{70}$ Furthur explanation can be seen in https://jamiatkheir.wordpress.com/ (accessed on September 16, 2016).

${ }^{71}$ See Enizar Muaz, "Jamiat Kheir: one of the pioneer of Pelopor Pembaharuan Lembaga Pendidikan Islam di Indonesia" (paper of Program Studi Arab, Universitas Indonesia, 1986), p. 37.
} 
policy had troubled Jamiat Kheir to open some branch offices in Indonesia. Instead, they gave different names - in spite of the vision and mission of their activists have the same goal as Jamiat Kheir. For example, in East Indonesia, there happened to be Al-Khairiyah which is in fact the branch of Jamiat Kheir- but in term of institution, they are different. That was one of the way to find solution in order to develop the existence of Jamiat Kheir. ${ }^{72}$

In the next stage, especially after Indonesia gained its independence on August 17, 1945, Jamiat Kheir then can find a freedom to show their vision and mission as well as the programs. According to an interview with the boards of Jamiat Kheir, since 1950s, Jamiat Kheir prefered to focus on educational school. At that time, the applied curriculum tent to adopt informal education system, especially in religious aspects. In 1908s, Jamiat Kheir began to adopt the government curriculum, particularly after the government issued Surat Keputusan Bersama (a joint decree) of three ministers. Nevertheless, Jamiat Kheir still applies local subjects as a part of showing the characteristics of the institution. ${ }^{73}$ The development of Jamiat Kheir as an Alawiyiin institution, which more focuses on education, tries to promote a more integral educational system, from kindergarten until higher education. ${ }^{74}$

The activities, that have been done by Bani 'Alawiyyin in the field of education (via Jamiat Kheir), show that they also disseminated Islamic mission peacefully and try to plant religious and national values in terms of Negara Kesatuan Republilk Indonesia (NKRI). Those are the way to get rid of radicalism and extremism of Islam in Indonesia.

\section{Conclusion}

In general, the role of Bani 'Alawiyyin in transmitting Islamic teaching of rahmatan lil 'álamin (blessing to universe) there will always be many factors. The factors, at least can support their success in disseminating Islamic teaching in Indonesia and Malay world are: First, the power of faith and sincerity in sending the message and task of religion. This is the most fundamental principle in facing the challenges

\footnotetext{
72 Interview with Dr. Husin in his office Rabithah Alawiyah on September 17, 2016.

${ }^{73}$ Interview with the board member of Jamiat Kheir in women dormitory of Jamiat Kheir on September 19, 2016.

${ }^{74}$ See: https://jamiatkheir.wordpress.com/lembaga/ (accessed on September 17, 2016).
} 
and problems of societies as the object of mission. Because without this courage, they will never be brave to cross the ocean and calamities in achieving the success of life. Second, the capability of appreciating cultures and local wisdom. It is important to have social capital in making adaptation and assimilation with social environment. The aptitude of Bani 'Alawiyyin in transforming values of Islam in the local context is part of successful strategy in transmitting Islamic mission in the world. Third, the skill master in many technical fields are needed. It can be seen in many skills, such as entrepreneurship, farming, and art skill. Fourth, the aptitude of communication and interaction with local figures. It is important to know that part of the strategy can reinforce relation between the poor and the have (elite). The preachers of Bani 'Alawiyyin had been successful in building networking system with several governments, local or national level. []

\section{References}

\section{Book and Articles}

Abushouk, Ahmed. "The Yemeni-Hadramis in Southeast Asia". Intellectual Discourse, 13, 2 (December, 2005).

Alatas, Syed Farid. "Hadhramaut and the Hadhrami Diaspora: Problems in Theoretical History". Ulrike Freitag and William G. Clarence-Smith (ed.). Hadhrami Traders, Scholars and Statesmen in the Indian Ocean, 1750s - 1960s. Leiden: Brill, 1997.

Al-Junaid Jamalullail, Muhammad bin Abdurrahman. "Syarīf AlAwliyā"”. Paper presented at al-Halaqah al-'Ilmiyyah al-Ūlā, January 12 -14, 2016 at Hotel Kartika Chandra, Jakarta.

Al-Masyhur, Abdurrahman bin Muhammad. Syams Az̧b-Zhabirah fi Nasab Abl Al-Bait min Bañ 'Alawī Furü' Fätbimah Az-Zabrä' wa Amir Al-Mu'minin 'Ali bin Abi Thalib. Jeddah: Alam Al-Ma'rifah, 1983.

Al-Masyhur, Idrus Alwi. Membongkar Kebohongan Sejarah dan Silsilah Keturunan Nabi S AW di Indonesia. Jakarta: Saraz Publishing, 2012.

Azra, Azyumardi. "Islamisasi Nusantara; Dakwah Damai". Peran Dakwah Damai Habaib 'Alawiyyin di Nusantara. Yogyakarta: Rausyan Fikr Institute and ICRO, 2013. 
Fauzi, Nurulwahidah, A. Yusuf, T. Ladjal and M. R. Nor, "Hadhrami 'Ulama' Within the Malay-johor Activism: The Role of Sayyid "Alw Bin Tahir Al-haddad (1934-1961)". Middle-East Journal of Scientific Research, 13, 3 (2013).

Freese, Lee and Peter J. Burke, "Persons, Identities, and Social Interaction". B. Markovsky, et al. (eds), Advances in Group Processes, vol. 11. (Greenwich, Conn.: JAI Press, 1994).

Huda, Nor. Islam Nusantara: Sejarah Sosial Intelektual Islam di Indonesia. Yogyakarta: Ar-Ruzz Media, 2013.

Jati, Wasisto Raharjo, "Radicalism in the Perspective of Islamic Populism: Trajectory of Political Islam in Indonesia". Journal of Indonesian Islam, 7, 02 (December 2013).

Mobini-Kesheh, Natalie, The Hadrami Awakening; Community and Identity in the Netherlands East Indies, 1900-1942 (Ithaca-New York: SEAP, 1999).

Muaz, Enizar. "Jamiat Kheir: Salah Satu Pelopor Pembaharuan Lembaga Pendidikan Islam di Indonesia". Unpublished bachelor thesis, Program Studi Arab, Universitas Indonesia, 1986.

Muzakki, Akh. "The Roots, Strategies, and Popular Perception of Islamic Radicalism in Indonesia". Journal of Indonesian Islam, 8, 1 (June 2014).

Sunyoto, Agus. Wali Songo: Rekonstruksi Sejaah yang Disingkirkan. Jakarta: Trans Pustaka, 2011.

Umar bin Hafizh, Habib. Agama Moderat: Menghidupkan Kembali Hakikat Ajaran Islam. Jakarta: Nurni Publishing, 2010.

Walker, Iain, "A Diaspora for Others: Hadramis in the World". Nando Sigona, et. al. Diasporas Reimagined: Spaces, Practices and Belonging. UK: Oxford Diasporas Program, 2015.

Weber, Max, Ethnic Groups in Roth G, Wittich C (eds). Economy and Society, Vol. 1. (Berkeley and Los Angeles: University of California Press, 1978).

\section{Online Sources}

https://damailahindonesiaku.com/deradikalisasi/ (accessed on 
September 14, 2016)

http://darulmurtadza.com/sejarah-majlis-talim-darul-murtadza/ (accessed on August 27, 2016).

http://iro.sg/ (accessed on October 07, 2016).

https://www.facebook.com/Baalwie.Mosque.Singapore/about/ (accessed on October 07, 2016).

http://majelisalmuwasholah.org/majelis-almuwasholah/ (accessed on August 19, 2016).

http://rabithah-alawivah.org/id/hippa-2/ (accessed on August 29, 2016).

https://jamiatkheir.wordpress.com/lembaga/ (accessed on September 17, 2016).

https://pecintahabibana.wordpress.com/2013/02/07/profil-darulmusthofa-tarim-hadhramaut/ (accessed on September 09, 2016).

https://www.hometeam.sg/article.aspx?news sid=20150513zPGPHt0 J7QRs (accessed on October 07, 2016).

http://www.kitaba.org/news/ba-alawi-mosque-a-model-forinclusion/ (accessed on October 07, 2016).

\section{Interviews}

Habib Zen Umar bin Smith in his office Rabithah Alawiyah (August 27, 2016).

Habib Ali Darul Murtadza (via telpon) in Malaysia (August 10, 2016).

Habib Hassan Al-Attas in Masjid Ba Alawy Singapore (August 06, 2016) and in his house on August 08, 2016.

Habib Muchsin Idrus Alhamid in FGD in his office Majelis AlMuwasholah (August 02, 2016).

Dr. Husin Alatas in his office Rabithah Alawiyah (September 17, 2016).

Habib Hamid Al-Qadri in FGD in his office Majelis Al-Muwasholah (August 02, 2016).

Board member of Jamiat Kheir in Jamiat Kheir of women building (September 19, 2016). 